\title{
Nature of Wife's Interest in Community Property in California
}

$\mathrm{F}$

IOR seventy-five years the courts of California have been deciding cases that involve the rights and obligations of husband and wife in the property of the community. They are no nearer today than they ever were to a clear-cut understanding of the nature of their interests. The reason for this confusion is not far to seek. It is simply this : minds trained to the common law have been unable to grapple successfully with a body of substantive laws that is sui generis. The remedy is not to be found by turning to the civil law, the ancestor of our community property system, for generations in the law of Califorma are reckoned by the sittings of the L.egislature. The truth is that the historical method has failed.

When, in Stezvart $v$. Stervart, the court was obliged to admit that,

" ... the interest of the wife ... is ... a much more definite and present interest than that of an ordinary heir,"

without being able to describe it any more definitely, it became evident at last that a new approach would have to be tried. In order to ascertain the true nature of the wife's interest it is necessary to look at her substantive rights, and from thein attempt, by inductive reasoning, to work out a comprehensive generalization. The historical inethod inust be abandoned for the scientific.

The wife's substantive tights are:

1. To obtain a division of the community property on divorce under Civil Code Section 146, or by force of Section $137 .{ }^{2}$

2. To dispose by will, as she sees fit, of one-half of the community property, if she predeceases her husband, or take possession of one-half if her husband predeceases her. ${ }^{3}$

3. To take that one-half in the event of her husband's prior death, in spite of any testamentary disposition by him to the contrary, although the whole of the property is subject to administration as if part of his estate. ${ }^{4}$

1 (1926) 72 Cal. Dec. 244, 260, 249 Pac. 197.

2 Goetting v. Goetting (1926) 51 Cal. App. Dec. 610, 252 Pac. 656.

8 Cal. Civ. Code, \$ 1401 .

4 ]Estate of Prager (1913) 166 Cal. 450, 137 Pac. 37. 
4. To treat as null and void, as to one-half of the community property, any sale made by her husband's executors, under a general power of sale contained in the will, beyond what is necessary to pay the debts or expenses of administration. ${ }^{5}$

5. To avoid, after her husband's death at least, any transfer made by her husband in violation of Section 172 of the Civil Code.

6. To avail herself of the rights in respect to community real property, conferred upon her by Section 172a of the Civil Code, as to the nature and enforcement of which the cases are in considerable conflict. ${ }^{\mathrm{B}}$

In the face of these rights and powers, can it be said that the wife has a "mere expectancy"? Of course she has a "mere expectancy" of enjoyment of possession; so has a vested remainderman. And yet there is only one case in all the California reports, i.e., Roberts v. Wehmeyer, in which it appears to have been argued that the wife has a vested interest in the sense of a vested future interest, a vested remainder. ${ }^{7}$ In that case it was unnecessary to the decision, and the court based its dictum on Estate of Burdick. ${ }^{8}$ The reasoning of the court in the latter case was that since the one-half which the wife gets upon her husband's death when she survives him, is subject to administration with his estate, she nust be an heir. But the answer is that it is subject to administration only for a limited

5 Estate of Wickersham (1903) 139 Cal. 652, 73 Pac. 541.

- The matter was thought to have been set at rest as to land by the new section of the Civil Code, $\$ 172(a)$, providing that "the wife must join" with the husband in selling, conveying, or encumbering, or leasing for longer than a year any community realty. But the cases of Rice v. McCarthy (1925) 47 Cal. App. Dec. 716, 239 Pac. 56, and Bone v. Dwyer (1925) 48 Cal. App. Dec. 257, 240 Pac. 796, have involved us in certain complexities. The former case interprets the new section as meaning that a conveyance by the husband to a bona fide purchaser is conclusively valid, and that the one year limitation on the wife's power to avoid refers to the exercise of the power in the case of a conveyance to a mala fide purchaser. The latter ease mentions Rice v. McCarthy, and apparently assents to the proposition that the presumption of validity is conclusive where the husband's sole conveyance is to a bona fide purchaser. The two cases are in conflict, however, as to the effect of a conveyance to one who does not act in good faith without knowledge of the marriage relation, the Rice case holding it voidable, the Bone case holding it void. But in Stewart v. Stewart (1926) 72 Cal. Dec. 244, 259, 249 Pac. 197, the court disagrees with both of the appellate courts. It says that the husband's sole conveyance to a bona fide purchaser is not conclusively valid, and that the one year limitation refers to such conveyance, a conclusion that the court in the Rice case says "would lead to an absurdity." The Stewart case mentions neither of the appellate cases. But the Rice case is a square decision that the husband's sole conveyance to a bona fide purchaser is conclusively valid. The Bone case is a square statement if not a decision that the husbands sole conveyance to a mala fide purchaser is wholly void.

7 Roberts v. Wehmeyer (1923) 191 Cal. 600, 606, 217 Pac. 746.

8 (1896) 112 Cal. 387, 44 Pac. 734. 
purpose, as proposition number 4, above, well exemplifies. ${ }^{\circ}$ The same: argument was made to the Arizona Court in $\mathrm{La}$ Tourette v. $\mathrm{La}$ Tourette. ${ }^{10}$ The discussion in that case is too illuminating to be ignosed. At the close of the opinion Chief Justice Franklin said,

"The lower court took jurisdiction of the whole of the community estate, and after paying the debts against it and the expenses of administration, distributed the residue. For in every case the community estate passes with the debts against it. It was not improper for the court to assume such jurisdiction of the community estate in order to determine the amount of the charges or debts thereon and direct their payment out of the property. Even if the decree of distribution added nothing to the strength of the widow's title to an undivided one-half of the property vested in her by law, it did definitely and finally determine the amount or extent of such interest freed from community obligation or debts. And it is immaterial whether it be denominated a decree of distribution or a judgment or order fixing the amount or extent of her interest in the community estate free of community charges or debts and which she is entitled to demand and receive from the executor, the desired end is accomplished."

The decisions in Louisiana, Texas and Washington, have allowed the wife a vested interest, although they have held that her share is subject to administration when her husband dies first. ${ }^{11}$ That the California court has not been wholly blind to the real reason for the whole community estate being thus subject to probate is shown by the following language in Harp v. Callahan :12

"Notwithstanding the fact that the mortgaged premises were community property, the wife's interest was subject to the payment of debts of the estate, and was an asset for that purpose in the hands of the administrator."

Estate of Burdick ${ }^{13}$ is not only demonstrably wrong, but the course of decision in the other community property states proves it to be wrong; let alone such penetrating comments as there are in the concurring opinion of Mr. Justice Harrison, and in the cases of Williams' Estate ${ }^{14}$ and Kohny v. Dunbar. ${ }^{15}$

9 Estate of Lux (1896) 114 Cal. 73, 45 Pac. 1023.

10) (1914) 15 Ariz. 200, 137 Pac. 426.

13. Bertrand's Succession (1909) 123 La. 784, 49 So. 524; Moody v. Looscan (1898 Tex.) 44 S. W. 621; First Nat'l. Bank v. Cunningham (1913) 72 Wash. 532, 130 Pac. 1148; Crowe \& Co. v. Adkinson Const. Co. (1912) 67 Wash. 420, I21 Pac. 841; Mager v. Big Bend Land Co. (1909) 51 Wash. 406, 99 Pac. 16.

1::(1873) 46 Cal. 222, 234.

13 (1890) 112 Cal. 387, 44 Pac. 734.

1.1 (1916) 40 Nev. 247, 161 Pac. 741.

1.i (1912) 21 Idaho, 258, 121 Pac. 544. 
If the premise were laid down that the wife is the present owner of a future interest in the community property, it would be easy to see that such an interest would carry with it a number of very definite rights. A certain veto power would naturally follow, in order to preserve the corpus of the property. It would be obvious that the precedent interest would terminate with the dissolution of the community, and the wife would come into enjoyment in person or through her heirs. There would be no confusion if there were a conditional limitation attached to the wife's interest, for instance, her death before her husband. It would not be startling for him to continue in possession of the corpus. It could be explained that the condition had been fulfilled and the limitation over to the husband had enabled him to remain in possession. Nor would it be disturbing, that the happening of the condition was, incidentally, one of the several ways of dissolving the community. There might still be another conditional limitation, namely the wife's dying intestate before her husband. If she died testate, he would have to transfer one-half of the community property to her devisees. We would not be aghast at a statute designed to make the transfer as painless as possible, such as a provision that the property should not be transferred to the wife's personal representative except to the extent necessary to carry her will into effect. Further, if the husband died first, so that the wife's future interest was consummated into a right of present possession, it would make very little difference if her share of the corpus were treated as part of his estate so long as it were subject to no liabilities beyond what the statute lawfully imposed. The fact that the husband's personal representative had a limited dominion over it for statutory purposes would not be a denial of her interest.

In the above paragraph, deductive reasoning is used to arrive at certain particular conclusions. Those conclusions happen to be part of the California law of community property. Why, given those particular facts, is it not possible to arrive at the same general conclusion by inductive reasoning? Is inductive reasoning a lost art? It ought not to be in this scientific age. It is clearly the scientific method of reasoning, as opposed to the classical, theoretical, deductive method. Anyone who is willing to start with the facts, and work back to a generalization based on them, instead of creating a generalization out of whole cloth, will find that the wife in California has a very real present ownership of an interest in all the community property. If the husband violates his statutory duty in respect of one particular piece of community property, her veto power arises 
in respect to that piece. She therefore obviously has an interest in it. This scientific investigator will speedily observe that the wife gets nothing by transfer, that her interest attaches as the property is acquired, that the only transfer is that of possession at the dissolution of the community (not necessarily her husband's death), and that the right to that possession does not come by transfer either, but is part of the original interest and awaits only the termination of the precedent estate, for its fulfillnent. This observer would also discover that his generalization would be difficult to express. He would try the common law labels, and find that none of them precisely fitted. But by avoiding words of art he could give a fair description of the nature of the wife's interest. He would, it is believed, say that it was a presently owned future interest, subject to a conditional limitation over in favor of the husband on certain events which have varied from tine to time according to different code amendments. ${ }^{16}$ If he were asked to say what her interest was not, as an intellectually honest man he would have to say that it was not the expectancy of an heir. If pressed he would explain that the expectancy of an heir refers both to physical possession, and the existence of a legal interest, whereas the expectancy of a wife is nore like that of a remainderman, an expectancy only as to physical possession.

Or, to approach the question with more particularity we see from the case of Dargie v. Patterson ${ }^{17}$ that the wife can revoke and avoid, as to specific property, a gift of that property niade by the husband during his lifetime. If her interest were as an heir, devisee or legatee, or a mere privilege or something which arose only by or through or because of the death of her husband, could she assert a specific right to specific property, regardless of, and nothwithstanding his attempted disposition otherwise?

When has an heir, devisee or legatee been able to do that?

Again, let us look at the cases, for example, Estate of Vogt, ${ }^{18}$ which enable the wife to take her share of the community property by the provisions of the law, instead of under the will. This is nothing but an instance of the doctrine of election, well known to the common law.

The doctrine of election, enabling the wife to choose between the will and her statutory right to one-half the community property, where the will seeks to supersede her community rights, necessarily

\footnotetext{
18 Cal. Civ. Code, $\$ \S 1401,1402$.

17 (1917) 176 Cal. 714, 169 Pac. 360.

18 (1908) 154 Cal. 508, 98 Pac. 265.
} 
indicates that she does not take as an heir. An heir takes by succession to the ancestor and out of his estate. But the doctrine of election exists only where there is a right independent of the estate, and adverse to it.

Aside from the doctrine of election we have another proof that her interest is adverse to her husband's estate, in the fact that the husband's executors by a valid sale of the community property are powerless to pass title to the wife's interest, unless the sale is to pay debts or the expenses of administration. ${ }^{\text {19 }}$

Nor does the wife have to wait for the death of the husband before coming into the enjoyment of her interest in the community property. That it is a living, constant right, is shown by Section 146, of the Civil Code, providing for a division of the counmunity property on divorce. This is a strange doctrine: that an "heir" can obtain her ancestor's property before his death, before the very event that is a condition precedent to the existence of any interest. She seems to have anything but a mere expectancy in these cases, and yet there they are, the law from the beginning, the law today. But the decisions go further and bring out in clear relief the nature of the wife's interest, by holding that even where the decree of divorce says nothing about community property, nevertheless the wife is entitled to an undivided one-half as a tenant in common. ${ }^{20}$ But if a wife, by operation of law, and not by court decree, can get the right to immediate possession and enjoyment of her share of the community property, during lier husband's life, how can it be asserted that she is merely his heir? Of course the courts admit that she is more than an heir. ${ }^{21}$ But they persist in saying that she has less than a property interest, not even a vested future interest. ${ }^{22}$ It is here that their reasoning has fallen down. It is this gap that has never been bridged. The question has been up squarely in the State Inheritance Tax cases. ${ }^{23}$ The result was that the wife was treated as an heir for one purpose, although she is more than an heir for almost every other purpose. The legislature hastened to exempt the wife's share from the inheritance tax and now the writer makes bold to challenge anyone to find any branch of the substantive law in California where the wife's rights are such that she must be an heir.

19 Estate of Wickersham (1903) 139 Cal. 652, 73 Pac. 541.

20 Kirschner v. Deitrich (1895) 110 Cal. 502, 42 Pac. 1064.

21 Stewart v. Stewart (1926) 72 Cal. Dec. 244, 260, 249 Pac. 197.

22 Roberts v. Wehmeyer (1923) 191 Cal. 601, 217 Pac. 746.

23 McDougald v. First Federal Trust Co. (1921) 186 Cal. 243, 199 Pac. 11. 
If the wife can get half the community property on divorce; if she gets that half by operation of law where the decree does not menticn the community property; if she can revoke a gift even as to specific property; can it be consistently said that she takes as an heir, ais one who can be defeated by the merest whim of the ancestor? Who ever heard of an heir being awarded one-half an ancestor's property upon divorce? Who ever heard of an heir who could dispose of an inheritance by will before the death of her ancestor? An heir has nothing, but a wife has testamentary power. Is that nothing? An heir can be disinherited, but not the wife. She can elect to take by law, and not according to her husband's will. This power of election is paramount and adverse to the estate of the decedent, but that of an heir is subordinate.

The answer to every one of these questions shows how truly the Supreme Court spoke in the Stewart case ${ }^{24}$ when it said that the wife's interest is more than that of an heir. In fact, it is not that of an heir at all. The trouble is that the courts have seen the husband's so-called absolute power of control, and have concluded that he must therefore be absolute owner, and that there was nothing left for the wife but a mere expectancy. But does it necessarily follow that ownership is absolute simply because the power of control is so great? It is submitted that it does not, and that no proposition could be better established in the law of California.

In Colburn v. Burlingame, ${ }^{25}$ a testator left property to a life tenant with a power of disposal expressed in varying terms, but in every case sufficiently broad to enable the life tenant to dispose of the entire principal if he so desired. The court reiterated that this absolute power of disposal did not in any case confer upon the life tenant the full ownership of the property, or any greater ownership than the will purported to give him. Indeed, it went further, and in Estate of Ritzman ${ }^{26}$ and Hardy v. Mayhew ${ }^{27}$ held that the power of disposal in the life tenant did not even make the remainder contingent.

The court, in the latter case, said,

"The distinction between the case of an intended gift of an absolute title to one with an attempted gift over of simply 'what

24 Supra, n. 20.

25 (1923) 190 Cal. 697, 214 Pac. 226. See also Estate of Ritzman (1921) 186 Cal. 567, 199 Pac. 783 ; Estate of Tooley (1915) 170 Cal. 164, 149 Pac. 514; Tuscomb v. Fintzberg (1912) $162 \mathrm{Cal}$. 433, 123 Pac. 247; Hardy v. Mayhew (1910) 158 Cal. 95, 110 Pac. 113; In re Garrity (1895) 108 Cal. 463, 38 Pac. 628, 41 Pac. 485; Estate of Mayhew (1906) 4 Cal. App. 162, 87 Pac. 417.

26 Supra, n. 25.

27 Supra, n. 25. 
remains unexpended' by the donee at the time of his death, where the gift over is void because in derogation of the absolute fee given the first taker, and the case of a gift of a life estate with a power of disposition for a particular purpose only, with an express gift over of what remains unused for such purpose, is recognized by all the authorities."

In the absence of a will, what have we to look to in dealing with the community property? Clearly the statutes, since the community property system is admittedly statutory. What ownership do these statutes give the husband? Section 172 of the Civil Code gives him management and control, with more limitations than in any one of the wills involved in the above cases. Section 1401 of the Civil Code sets the time limit on this management and control as to the wife's half, making it end with the wife's death before her husband, testate, or the husband's prior death. Only if the wife dies first intestate, or by decree of divorce under special circumstances, can his control continue. Is it not clear then that the normal interest the husband has is a life estate in the wife's half of the community property? There are only two contingencies in which his ownership can carry beyond the end of his own life, namely, the wife's prior death intestate, and divorce based upon special grounds. But his control may be cut short before the end of his own life either by her prior death testate, or by divorce under the usual circumstances.

How can we best express this in common law terms? Clearly none of them fit perfectly. If they did, this question would have been settled long ago. An analogy might be drawn to the common law "life estate, pur autre vie"; the "other life" in this case being the life of the community. But the analogy is imperfect because the common law knew no "autre vie" but that of a living person, and because the common law estate pur autre vie was subject to be made vacant by the death of the tenant before that of.the other person, and it was then a case of "first come, first served." There is no parallel to such a situation in the community property law. A tentative description is this:

The husband has a life estate, with a vested remainder in fee in the wife, subject to a conditional limitation in favor of the husband in fee in the event of the reife's prior death intestate, or in the discretion of the court, if he gets a divorce for adultery or extreme cruelty.

There are two events in which the husband's estate may be destroyed before his death, namely: First, divorce, or second, the wife's death testate. 
In the first place let us consider divorce. If there is a divorce the husband's life estate is subject to the contingency of being cut shori. In other words, the wife's enjoyment of her vested remainder is accelerated by the destruction of the precedent community estate. It is a "coming in" upon a destruction of the preceding estate that is known as the "acceleration of the remainder," and by the weight of a1thority, only vested remainders will accelerate.

In Swann v. Austel, ${ }^{28}$ the court said,

"We do not think that the remainder estate was accelerated by Mrs. Austel's renunciation of the provisions of the will in her favor. If the relnainders were contingent, there was no acceleration, because acceleration applies only in the case of vested remainders." 29

In fact a close perusal of the cases will indicate that in reality the rule is general that only vested remainders will accelerate and when remainders that are apparently contingent are allowed to accelerate, the event terminating the precedent estate has also determined the contingency and vested the remainder. ${ }^{30}$

But there are only two contingencies that can deprive her of the ultiniate enjoyinent in possession of her one-half, i.e., her death intestate, and divorce in a limited class of cases. Neither of those contingencies has happened. The divorce accelerating her interest cannot be construed as a death intestate, nor can it be readily identified with a divorce that cuts off her interest. The remainder, therefore, must be vested, or it would not accelerate. But the contingencies, since they do not prevent acceleration, although they have not been determined, must be conditions subsequent.

Secondly, in considering the wife's death testate we come to the other event whereby the husband's life estate in his wife's half of the community property may be terminated prior to his death. That event is the wife's prior death leaving a valid will disposing of her share of the community property. The husband's estate is subject to this event. How shall it be described in coinmon law language? Only in one way can it be described, namely, that the husband's life estate is subject to a power of appointment in the wife. It will be argued that, under Section 781 of the Civil Code, a power of appointment cannot prevent a future estate from vesting and there-

$2: 3$ (1919) 261 F. 465, 469.

29 See also Northern Trust Co. v. Wheaton (1911) 249 I1l. 606, 94 N. E. 980; Hasemeier v. Welkie (1923) 309 I1l. 460, 141 N. E. 176; Brandenburg v. Thorndike (1885) 139 Mass. 102, 28 N. E. 575; Maynard v. Maynard (1919) 108 Misc. Rep. 362, 178 N. Y. Supp. 329; Compton v. Barbour (1919) 124 Va. 548,98 S. E. 651 .

${ }^{310}$ Crosson v. Crosson (1924) 303 Mo. 572, 262 S. W. 701; Cockey v. Cockty (1922) 141 Md. 850, 118 Atl. 850. 
fore the estate in fee in favor of the husband in the event of the wife's dying intestate before him is vested, and merges with his life estate to give him absolute ownership, subject to certain contingencies in favor of the wife, and that therefore the wife's future interest, not the husband's, is contingent. Such reasoning, however, leaves out of account the fact that the wife's power of appointment is so limited that she may fail to execute it and still the husband will not have the fee. Such is the case where the husband dies first, or where the wife is awarded her share upon a divorce. In such event the wife gets her half, and yet she has not executed her special power of appointment. In other words, the husband's future estate is not "limited to take effect in case such power is not executed," and therefore Section. 781 does not apply. If the husband's future interest were so limited, all he would have to do would be to die before his wife. Then she would have failed to execute her power, and he, by his successors, would take the fee. But Section 1401 of the Civil Code expressly provides that she has something beyond this special power, namely the right to the fee in one-half the community property upon surviving her husband. That is the central fact. It is that fact that gives her a remainder. It puts up to us the problem of deciding whether the remainder is vested or contingent. If we were dealing with a will we would look to the intent of the testator. Not having a will, we must look to the intent of the substantive law. There we find that this condition of her not dying intestate before her husband cannot be precedent so as to make her remainder contingent, because she can come into possession without that condition's happening. The condition, then, must be subsequent. There is nothing else it can be. The condition being subsequent, there is nothing to prevent her remainder from being vested. In the words of Section 694 of the Civil Code,

"there is a person in being who would have a right, defeasible or indefeasible, to the immediate possession of the property upon the ceasing of the intermediate or precedent interest."

The wife's right is defeasible in the event of her dying intestate before her husband, or in the event of the husband's obtaining a divorce for adultery or extreme cruelty. Any event that can terminate the husband's life estate, i.e., her death testate, his death, or divorce, finds a person in being (either the wife herself or her successors in interest) with a right to the immediate possession of her half of the community property. As the court said in Re De Vries, ${ }^{31}$

“. . . . we find here 'the existence in an ascertained person

31 (1911) 17 Cal. App. 184, 202, 119 Pac. 109. 
of a present fixed right' of future enjoyment. In other words. we can here 'point to a person who, if the life estate should cease, would' eo instanti et ipso facto have an immediate right of possession,' and this as the court of appeals of New York says, in Moore v. Littel, $41 \mathrm{~N}$. Y. 80, 'is a vested remainder, and, by necessary consequence, all the contingencies which may operate to defeat the right of possession are to operate, and only to operate, as conditions subsequent." "

It may be argued that it is not every divorce that gives her a right to one-half of the community property. Her husband may get a divorce for adultery or extreme cruelty, and have the entire comrnunity property awarded to him. Is the wife's interest therefore contingent? The answer is that every divorce that terminates the luusband's life estate as to any moiety of the community property does give her a right to that moiety. Of course the taking place of a divorce is a contingency that may not happen, but so is any other event that destroys a life estate before its natural termination, and. for the succeeding interest to come into immediate possession shows either that it was vested or that the conditions precedent on which it was limited have already happened.

Now, whichever the event may be that accelerates the wife's enjoyment, the usual type of divorce or her predeceasing her husband, leaving a valid will, it is neither her death intestate before her husband nor a divorce of that limited class that deprives her of the community property. Therefore the apparent argument against her remainder being vested is in reality but another proof that it is vested.

In addition, however, to the inescapable logic of the situation we have the well-known axiom of the law "if the question be doubtful, the rule is to construe the estate as vested rather than contingent." ${ }^{32}$ This in itself ought to be conclusive.

The result then is: The husband has a life estate in the wife's half of the community property, followed by a vested remainder in. fee belonging to the wife, this remainder being subject to be cut short in favor of the husband by the wife's predeceasing him intestate, or in the court's discretion upon his obtaining a divorce for extreme cruelty or adultery. The wife has, moreover, a special power of appointment, the exercise of which destroys the husband's life estate and accelerates her remainder in favor of appointees. Furthermore, upon a divorce, exclusive of the class of divorces above meniioned, the husband's life estate will be destroyed and the wife's remuinder accelerated. San Francisco, California.

Robert G. Hooker, Jr.

32 Miller v. Oliver (1921) 54 Cal. App. 495, 202 Pac. 168. 